\title{
Students' Perceptions of the Impact of the College English Test
}

\section{HONGLI LI}

Georgia State University, USA

QI ZHONG

Central University of Finance and Economics, China

\section{HOI K. SUEN}

The Pennsylvania State University, USA

\author{
Bio Data: \\ Hongli Li is an assistant professor of Research, Measurement, and \\ Statistics in the Department of Educational Policy Studies at Georgia \\ State University, USA. Her research interests include the use of testing \\ to inform teaching and learning, diagnostic assessment of reading \\ comprehension, and language testing.
}

Qi Zhong is a lecturer with the School of Foreign Languages at the Central University of Finance and Economics, China. Her research interests include teaching English as a second language, comparative literature and culture, and business English speech.

Hoi K. Suen is a distinguished professor of Educational Psychology at The Pennsylvania State University, USA. His research interests include measurement theories, behavioral observation, validity issues, consequences of high-stakes testing, and lessons from the historical civil service exam system of China.

\begin{abstract}
Designed to assess college students' English ability, the College English Test (CET) is regarded as the most influential English test in China. This study investigates students' perceptions of the impact of the CET on their English-learning practices and their affective conditions. A survey was administered to 150 undergraduate students at a university in Beijing. It was found that students perceived the impact of the CET to be pervasive. In particular, the majority of the respondents indicated that the CET had a greater impact on what they studied than on how they studied. Most of the students surveyed felt the CET had motivated them to make a greater effort to learn English. Many students seemed to be willing to put more effort on the language skills most heavily weighted in the CET. About half of the students reported
\end{abstract}


a higher level of self-efficacy in regard to their overall English ability and some specific English skills as a result of taking or preparing for the CET. However, many students also reported experiencing increased pressure and anxiety in relation to learning English. This study provides important evidence about how the CET influences college students' English learning in China, and directions for further research are also suggested.

Keywords: Students, Perceptions, Impact, College English Test

\section{Introduction}

Launched by the Ministry of Education, People's Republic of China, in 1987, the College English Test (CET) is a standardized test designed to measure the English proficiency of undergraduate students in China and to determine whether their English-language ability meets the requirements of the national college English curriculum. In accordance with the national curriculum, the CET consists of two tests: Band 4 (CET-4) and Band 6 (CET-6). College students are expected to take the CET-4 at the end of their second year in college. Students are eligible to take the CET-6 only after they have passed the CET-4. The CET-4 is usually required, whereas the CET-6 is optional. Both the CET-4 and the CET-6 are held twice a year: in June, at the end of the spring semester, and in December, at the end of the fall semester. Students can take the test multiple times while in college.

Traditionally, the CET consisted of five sections: listening, reading, vocabulary and structure, cloze (error-correction and/or question answering), and writing. The total possible score was 100, with a mean of 72 and a standard deviation of 12. Certificates were issued to examinees who achieved a score of over 60 . However, with the issuance of the National College English Curriculum Requirements (NCECR, Ministry of Education, 2004), the CET underwent some major changes. For example, as of June 2005, a new scoring system was adopted, which has a maximum score of 710, a mean of 500, and a standard deviation of 70 . Score reports are provided to examinees in order to provide feedback to guide their subsequent efforts to learn English. More importantly, as the NCECR aims to promote communicative English skills such as listening and speaking, the contents of the CET were adjusted accordingly in 2006. For example, the weight of the listening section was increased from $20 \%$ to $35 \%$; the vocabulary and structure section, which originally constituted $15 \%$ of the total score, was removed. Skimming and scanning was introduced to the reading section, which now constitutes $35 \%$ of the total score. Translation (or short-question answering) became a regular section and constitutes $5 \%$ of the total score, and the weight of the writing section remains the same at $15 \%$.

The CET is regarded as the most influential English test in China, and it is the language test administered to the most students nationwide (Jin \& Yang, 2006). According to Jin $(2008$, p. 2), the chair of the CET committee, "the CET is now taken by almost every college and university non-English-major student in China," and as many as 12 million students took the test in 2006. Before the reform of the CET in 2005, as reported by Yu (2005), 81.7\% of Chinese universities regarded passing the 
CET-4 as a precondition for earning a bachelor's degree. With the new scoring system introduced in 2005, the CET certificate is not issued any more; however, some universities still require a minimum CET-4 score, such as 426 , in order for students to receive a bachelor's degree. Employers take a similar view: "CET certificates [or scores] have become a nationally recognized credential for employment of college and university graduates" (Jin, 2008, p. 4). For instance, CET scores have even been used to determine whether college students are eligible for residence permits in some major cities (Jin, 2008).Overall, the CET has had a farreaching educational and social impact in China, and its impact has become a correspondingly important and highly contentious issue not only in academia but also in Chinese society (Jin, 2008; Yang, 2003). Many assert that the CET has driven the enforcement of the national curriculum and made a massive contribution to college English teaching in China (e.g., Gu, 2005; Yang, 2003). Meanwhile, the CET is criticized for inducing students to focus their English learning efforts on the test, i.e., to "study to the test," thus turning college English education into CET preparation (e.g., Cai, 2005; Chen, 2008; Han, Dai, \& Yang, 2004).

Wall (1997) defined test impact as "any of the effects that a test may have on individuals, policies or practices, within the classroom, the school, the educational system or society as a whole" (p. 291). Among the many stakeholders, students are probably the most important group, as major decisions are made about them based on their test results (Kirkland, 1971). However, most of the studies on the impact of the CET (e.g., Chen, 2007; Gu, 2005; Hua, 2006; Wang, Wang, \& Liu, 2005) have focused on teachers. Overall, there is a dearth of empirical evidence in regard to the impact of the CET on students; and, in particular, data is scarce in regard to their affective conditions, such as feelings, attitudes, and moods. Thus, the present study investigates students' perceptions of the impact of the CET on their English-learning practices and on their affective conditions, in order to enable school administrators, teachers, parents, test designers, and policy makers, as well as students, to become better informed about how the CET influences students. The current study focuses on the CET-4, as it is more influential than the CET-6.

\section{Literature Review}

In the past several decades, the impact of tests has been the subject of considerable attention from educators and researchers - especially in the field of language testing. The term frequently used in language testing is "washback," defined by Hughes as"the effect of testing on teaching and learning" (1989, p. 1). In this paper, "washback" and "impact" are used interchangeably (Andrews, Fullilove, \& Wong, 2002). The washback hypotheses proposed by Alderson and Wall (1993) provide clear guidelines on the areas that might be influenced by washback. For example, a test will influence teaching and learning; a test will influence what teachers teach and how they teach; a test will influence what learners learn and how they learn; and a test will influence the rate, sequence, degree, and depth of teaching and learning. Hughes (1993) identified three key mechanisms within the washback process, i.e., participants, process, and products. The participants are those whose perceptions of their work may be affected by a test, including students, teachers, administrators, materials developers, and publishers; the process is any action taken by the 
participants that contributes to the learning process; and the products refer to what is learned and the quality of the educational outcomes. According to Hughes (1993), a test will first influence the participants' perceptions and attitudes, then how they perform, and finally the learning outcomes. Furthermore, washback can be considered positive (beneficial) or negative (harmful) (Taylor, 2005).Positive washback encourages good teaching and learning practices, whereas negative washback encourages bad teaching and learning practices.

Language testing researchers have conducted numerous studies examining the nature of washback, how it works, and its effects. Wall and Horak (2007), for example, offered a summary showing that a variety of studies have examined the impact of international tests such as the Test of English as a Foreign Language (TOEFL) (Alderson \&Hamp-Lyons, 1996; Hamp-Lyons \& Brown, 2005), the First Certificate in English (FCE) (Tsagari, 2006), the International English Language Testing System (IELTS) (Green, 2006; Hawkey, 2006; Hayes \& Read, 2004), the Hong Kong Certificate of Education Examination in secondary schools (Cheng, 1997), the National Matriculation English Test (NMET) in China (Qi, 2007), the College Entrance Examination in English as a Second Language in Japan (Watanabe, 1996), and the Certificate in Spoken and Written English (CSWE) in the Australian Adult Migration Program (Burrows, 2004). The most common findings are these: tests do influence teaching and learning; tests tend to bring faster and more changes in teaching content than in teaching methods; and washback is more complicated than was first thought. However, as Wall (2000) observed, most studies have focused on how testing influences classroom teaching, where as studies on how testing influences students' learning and their behaviors are relatively few.

Of the studies on the CET washback, Gu's (2005) study is probably the most comprehensive one. Based on classroom observations at a local university and questionnaire surveys conducted nationwide in China, she found that most stakeholders perceived more positive washback of the CET on classroom teaching and learning. Specifically, the CET had great influence on teaching content, teaching pace, and teachers' attitudes towards teaching than on the teaching methods. Further, the CET was important in motivating schools to adhere to the national curriculum and induced school administrators to attach greater importance to English courses. However, some negative washback was also perceived, such as a faster teaching pace, the use of coaching materials in class, and being unable to complete the textbook materials ( $\mathrm{Gu}, 2005)$.

To investigate the washback of the new CET, Gu, Yang, and Liu (2011) revisited the classrooms of the three college English teachers who participated in the classroom observation portion of Gu's 2005 study. They concluded that the essential mode of college English teaching, being teacher-dominated, remained the same over years, though the CET has undergone noticeable changes. However, the teachers did spend more time on listening, skimming and scanning, and translation, i.e., the skills that have more weight in the new CET than they had in the earlier version. This follow-up study agrees with the previous baseline study $(\mathrm{Gu}, 2005)$ that the CET has a greater influence on the content taught than on teaching methods.

Huang and Yang (2002) studied the washback of the CET in 11 universities in China. They found that the CET exerted an influence on various aspects of college 
English teaching and learning, and that the majority of teachers and students believed the CET yielded more positive washback than negative. They also concluded that different types of institutions and students experienced different intensities of washback. For example, the higher-ranking universities perceived less influence compared to the lower-ranking universities, and the first-year students perceived less influence than the second-year students. Hua (2006) examined the washback of the CET in three teachers' colleges. She found that the CET did not exert much influence on how college English teachers taught when students were in their first three semesters of college. However, as the CET approached during the fourth semester, the teaching strategies, teaching materials, and teaching activities in the class all focused on preparing the students to pass the CET. In addition, Li (2009) examined the impact of the CET writing section on the teaching of writing at a university in China. She observed that the CET did not change the way teachers taught English writing, probably due to the relatively low requirement of the CET writing section, its restrictive testing format, teachers' lack of training on how to teach writing, and the large class size.

Overall, in the literature on CET washback, researchers have tended to focus on the impact of the CET on teaching activities, whereas students' perceptions of the CET have met with scant attention. Students are actually the primary stakeholders in testing situations, as it is the student "whose status in school and society is determined by test scores and the one whose self-image, motivation, and aspirations are influenced" (Kirkland, 1971, p. 307). Rea-Dickins (1997) also contended that students are perhaps the most important stakeholders and "their views are among the most difficult to make sense of and to use" (p. 306). Furthermore, most studies have focused on academic factors, whereas students' affective conditions have been neglected. It is, therefore, important to directly assess how students feel about the impact of the CET, both in terms of their English-learning practices and affective conditions.

In an extensive literature review, Kirkland (1971) concluded that tests could influence factors such as a student's self-concept, motivation, level of aspiration, study practices, and anxiety. First, test scores influence a student's self-concept. Depending on a student's opinion regarding the accuracy of the test results, opinion of his/her performance on the test, capabilities, and other individual characteristics, tests can have a positive or negative influence on a student's self-concept. Second, the stakes of a test, the frequency with which it is given, and expectations of success or failure on the test can influence a student's motivation in regard to it. Third, level of aspiration refers to the level of achievement that a student expects to reach, and it is also related to both self-concept and motivation. Successful performance on a test increases the level of aspiration but failure on a test decreases it. Fourth, study practices refer to the ways in which a student studies in preparation for a test. It has been found that different types of tests, such as open-book versus closed-book, multiple-choice versus essay questions, influence a student's study practices differently. Finally, anxiety and tension are always associated with taking tests. Those who anticipate encountering difficulties during the test may experience more anxiety than those who have no such expectations. In particular, Harlen and DeakinCrick (2003) reviewed the impact of tests on student motivation, finding a complex 
interaction between motivation and other factors, such as effort, goal orientation, locus of control, self-efficacy, sense of self as a learner, self-esteem, self-regulation, and interest.

Based on the literature, we propose that the CET impacts students in two ways: academic and affective. The academic impact refers to the CET's influence on students' English-learning behavior, as this pertains to learning content(i.e., what students study) and learning methods (i.e., how they study), whereas affective impact refers to the CET's influence on students' affective conditions, such as goal orientation, motivation, self-efficacy, and anxiety.

\section{Methods}

\section{Context and Participants}

This study took place at a university in Beijing, one of the high-ranking universities in China. As this university requires its students to have high college entrance examination scores in order to enroll, its students' English language proficiency is generally higher than the national average. All the students are required to take English courses consecutively for four semesters in their first two years. At the end of the fourth semester, students take the CET-4, and those who fail will retake the test during the rest of their college years. Those who pass the CET-4 usually will proceed to take the CET-6. However, this university does not require students to achieve a certain score on the CET-4 in order to receive a bachelor's degree.

In May 2008, a few weeks before the CET-4 was scheduled, 150 students completed a questionnaire that asked them how they felt about the impact of the CET-4. Of the students who provided demographic data, 109 were female and 38 were male; there were 49 first-year students, 56 second-year students, 41 third-year students, and 2 fourth-year students. At the time of the survey, the third-year and fourth-year students had already taken the CET-4, the second-year students were scheduled to take the CET-4 in a few weeks, and the first-year students would not take the CET-4 until a year later.

\section{Instrumentation and Data Collection}

A questionnaire was constructed to solicit students' perceptions of the impact of the CET-4.(Unless otherwise specified, the CET refers solely to the CET-4 in the subsequent section and the questionnaire). First, we drafted items under the categories as set out in the previous literature review (e.g., Alderson \& Wall, 1993; Gu, 2005; Huang \& Yang, 2002; Kirkland, 1971), such as learning content, learning methods, goal orientation, motivation, self-efficacy, and anxiety. Second, two outside experts were invited to comment on whether the questionnaire statements examined students' perceptions of test impact as informed by the literature. For example, the experts suggested adding "as a result of taking or preparing for the CET" to the items about self-efficacy, so that participants would be able to appropriately attribute the change of their self-efficacy to their experience with the CET. The experts also suggested revisions in regard to improving the clarity, accuracy, and independence of the items. For example, the item "I am a better learner of English because of the CET" was criticized as being too general. As suggested by the experts, 
this item was changed to "Taking or preparing for the CET influences the way I learn English."Finally, we translated the English questionnaire into Chinese. A Chinese-English bilingual researcher was invited to evaluate the translation, and minor revisions in regard to wording were made based on this researcher's suggestions.

Next, we ordered the items randomly for the final draft of the questionnaire. The first part of the questionnaire comprised demographic information, whereas the second part comprised 4-option, forced-choice Likert-type items asking students to select whether they strongly agreed, agreed, disagreed, or strongly disagreed with each statement about the impact of the CET. Copies of the questionnaire, now rendered in Chinese, were distributed to 150 undergraduate students with the help of their English instructors. All the 150 students completed and returned the questionnaires to the researchers.

\section{Results and Discussion}

\section{Learning Content and Learning Methods}

Five items related to students' perceptions of how the CET impacted their Englishstudy behavior. Table 1 shows the percentage of the students who strongly agreed (SA), agreed (A), disagreed (D), or strongly disagreed (SD) with each item. The items are listed in descending order of the overall percentage of SA and A responses. In other words, the item listed at the top has the highest percentage of SA and A responses, whereas the item at the bottom has the lowest percentage of SA and A responses. This organizational principle applies to all the tables in this paper.

Table 1

Learning Content

\begin{tabular}{lllll}
\hline Items & SA & A & D & SD \\
\hline $\begin{array}{l}\text { I will work hard to practice English speaking if it is } \\
\text { required on the CET. }\end{array}$ & 56.7 & 20 & 2 \\
\hline $\begin{array}{l}\text { I will spend more time practicing English listening if } \\
\text { listening gets heavier weight in the CET. }\end{array}$ & 56.7 & 17.3 & 4.7 \\
\hline $\begin{array}{l}\text { I am more attentive in the class if the teacher lectures on } \\
\text { contents related to the CET. }\end{array}$ & 63.3 & 20.7 & 3.3 \\
\hline $\begin{array}{l}\text { I pay more attention to the content that is related to the } \\
\text { CET. }\end{array}$ & 5.3 & 32 & 4.7 \\
\hline $\begin{array}{l}\text { I pay more attention to the words that are labeled as } 8.7 \\
\text { CET vocabulary. }\end{array}$ & 45.6 & 38.3 & 7.4 \\
\hline
\end{tabular}

Note: SA =Strongly Agree, A = Agree, $\mathrm{D}=$ Disagree, SD = Strongly Disagree. All the numbers in the cells are percentages.

It can be seen that $78 \%$ of the students agreed or strongly agreed that they would work hard to practice English speaking if speaking were required on the CET. Speaking was added to the CET in 1999 as an optional section and has remained so. Only when students have achieved an advanced-level rating of 550 for CET-4 or 520 
for CET-6, do they become eligible to take the CET speaking test (Zhang \& Elder, 2009). According to the students' responses, if speaking were to become a required section of the CET, the majority of students would place more emphasis on developing their English-speaking ability. Likewise, $78 \%$ of students agreed or strongly agreed that they would spend more time practicing English listening if it were more heavily weighted in the CET. In 2006, the weight given to the listening section was raised from $20 \%$ to $35 \%$ with the purpose of encouraging students to develop communicative language skills. Though causal relations are difficult to make here, it is reasonable to assume that the changes in the CET with regard to listening skills affected students' attitudes regarding improving their communicative skills in English.

Similarly, $76 \%$ of the students agreed or strongly agreed that they would be more attentive in class if the teacher were to lecture on content related to the CET. In a related CET washback study, $\mathrm{Li}$ (2009) reported that students sometimes requested teachers to coach them on the CET in class, especially when the test was approaching. Therefore, some English teachers complained that the CET interfered with their regular classroom teaching $(\mathrm{Gu}, 2005$; Hua, 2006). Likewise, 63\% of students agreed or strongly agreed that they would pay more attention to the content that is related to the CET, which again tends to confirm the CET's influence on learning content. Furthermore, more than half the students agreed or strongly agreed that they would pay more attention to the words labeled as CET vocabulary. The CET Committee publishes manuals with words that might appear in their tests; thus, in the college English textbooks and the CET coaching materials, some words are labeled as CET-4 vocabulary and some more challenging ones are labeled as CET-6 vocabulary. Therefore, it is likely that students would pay particular attention to the words labeled as CET vocabulary.

Table 2 summarizes the four items related to learning methods. Over $75 \%$ of the students agreed or strongly agreed that they had taken or would take the CET coaching classes, and over $60 \%$ would buy or had bought the CET coaching materials. After-school CET coaching classes have become pervasive in China. Such classes not only provide intensive training on how to learn English but more importantly they offer training on test-taking strategies. Furthermore, a large number of CET coaching materials are on the market for students to purchase. However, the quality of the CET coaching classes and materials vary greatly, and they also add considerably to the financial burden of college students. Still, the results of this study show that more than half of the participating students would resort to CET coaching classes and/or purchase CET coaching materials.

Around $45 \%$ of the students agreed or strongly agreed that they would try any learning method that might help them perform better on the CET. Still, only about $29 \%$ of the students thought that taking or preparing for the CET influenced the way they learned English. There is consistent evidence showing that tests have a stronger influence on teaching content than on teaching methods (e.g., Cheng, 1997; $\mathrm{Gu}, 2005 ; \mathrm{Li}, 2009)$. Accordingly, the current study shows that the CET tended to change the content the students studied more than the ways in which they studied it. Traditionally, English learning in China tends to be test-oriented, book-centered, with plenty of drills and exercises that emphasize rote memorization rather than 
communicative skills (Rao, 2001). This particular learning style is the outcome of the sociocultural, economic, and historical setting of China ( $\mathrm{Li} \& \mathrm{Su}, 2006)$, and thus it is likely to be difficult to change in a short time.

Table 2

Learning Methods

\begin{tabular}{lllll}
\hline Items & SA & A & D & SD \\
\hline I have taken or will take the CET coaching classes. & 24.7 & 50.7 & 17 & 7.3 \\
\hline I will buy or have bought CET coaching materials. & 13.3 & 48.7 & 31 & 7.3 \\
\hline $\begin{array}{l}\text { I would like to try any learning methods that can help me } \\
\text { perform better on the CET. }\end{array}$ & 4.7 & 38.9 & 48 & 8.1 \\
$\begin{array}{l}\text { Taking or preparing for the CET influences the way I } \\
\text { learn English. }\end{array}$ & 22 & 43 & 29.3 \\
\hline
\end{tabular}

Note: $\mathrm{SA}=$ Strongly Agree, $\mathrm{A}=$ Agree, $\mathrm{D}=$ Disagree, $\mathrm{SD}=$ Strongly Disagree. All the numbers in the cells are percentages.

\section{Goal Orientation and Motivation}

Goals provide students with direction and a purpose for engaging in an activity (Pintrich\&Schunk, 1996), and goal orientations constitute students' reasons for engaging in academic tasks (Anderman, Austin, \& Johnson, 2002). Three items are related to goal orientation. As shown in Table 3, over half of the students agreed or strongly agreed that taking or preparing for the CET led them to have clearer English-learning goals. However, only one third of them agreed or strongly agreed that passing the CET was their major driving force for learning English, and only $20 \%$ agreed or strongly agreed that passing the CET was their major purpose for learning English.

Table 3

Goal Orientation

\begin{tabular}{lllll}
\hline Items & SA & A & D & SD \\
\hline $\begin{array}{l}\text { Taking or preparing for the CET makes me have clearer } \\
\text { goals in learning English. }\end{array}$ & 45.3 & 38 & 6.7 \\
$\begin{array}{l}\text { To pass the CET is my major driving force in learning } \\
\text { English. }\end{array}$ & 26.7 & 40.7 & 27.3 \\
$\begin{array}{l}\text { To pass the CET is my major purpose for learning } \\
\text { English. }\end{array}$ & 14.7 & 51.3 & 28.7 \\
\hline $\begin{array}{l}\text { Note: SA =Strongly Agree, A = Agree, D = Disagree, SD = Strongly Disagree. All } \\
\text { the numbers in the cells are percentages. }\end{array}$
\end{tabular}

The historical civil service exam in China has dominated the history of the Chinese educational system, and it still influences schooling practices today (Suen \& $\mathrm{Yu}, 2006)$. Specifically, English-language tests are used as gate-keeping devices for access to general employment and higher education in China (Ross, 2008). It is, therefore, not surprising that English-language education is intensively test-oriented 
in China. Many students learn English for the sake of taking the tests instead of for using the language for real purposes. Therefore, for many students, the CET appears to be one of their goals for learning English in college. In addition to the CET, other English tests that college students can take include the graduate school entrance examination in China and international English tests such as the Test of English as a Foreign Language (TOEFL), the Test of English for International Communication (TOEIC), the International English Language Testing System (IELTS), and the Business English Certificate (BEC) (Jin, 2008). According to Hua (2006), 70\% of the students reported that they were motivated to learn English by the CET; $14 \%$ reported that their motivation was to pass the graduate school entrance examination, and $10 \%$ were motivated to improve their English language abilities. In Hua's view, these results reflect the fact that the students in her study were likely to remain in China as public school teachers, such that few would have a need to present scores from international English tests. In the current study, however, the participating students were from a high-ranking university, and many of them intended to enroll in graduate schools in China or abroad. This partially explains why most of them did not regard passing the CET as their major purpose for learning English.

A concept related to goal orientation is motivation, which "is the process whereby goal-directed activity is instigated and sustained" (Pintrich \& Schunk, 1996, p. 4). Motivation is a broader concept, and different theoretical models have been developed to describe it. Motivation in the present study is mainly operationalized by how much effort the students were willing to make to pass the CET. Table 4 shows the results of 12 items related to motivation. To begin with, over $80 \%$ of the students agreed or strongly agreed that taking or preparing for the CET made them more motivated to learn English. Seventy-four percent agreed or strongly agreed that they spent more time learning English because of taking or preparing for the CET. More than half of the students agreed or strongly agreed that the CET made them feel that English was a very useful tool, and taking or preparing for the CET made them feel that English learning was more important.

Table 4

Motivation

\begin{tabular}{lllll}
\hline Items & SA & A & D & SD \\
\hline $\begin{array}{l}\text { Taking or preparing for the CET makes me more } \\
\text { motivated to learn English. }\end{array}$ & 66 & 14 & 2.7 \\
\hline $\begin{array}{l}\text { I spend more time learning English because of taking or } \\
\text { preparing for the CET. }\end{array}$ & 52 & 20.7 & 5.3 \\
$\begin{array}{l}\text { In order to prepare for the CET, I spend more time } \\
\text { memorizing English words. }\end{array}$ & 58 & 24 & 4 \\
\hline $\begin{array}{l}\text { In order to prepare for the CET, I spend more time } 12 \\
\text { watching English movies. }\end{array}$ & 58.7 & 26 & 3.3 \\
$\begin{array}{l}\text { In order to prepare for the CET, I spend more time } \\
\text { listening to English broadcasts. }\end{array}$ & & & & \\
\hline $\begin{array}{l}\text { In order to prepare for the CET, I spend more time } \\
\text { practicing English-Chinese translation. }\end{array}$ & 58.7 & 28 & 2.7 \\
\hline
\end{tabular}


In order to prepare for the CET, I spend more time $\begin{array}{lllll}10 & 54.7 & 30 & 5.3\end{array}$ practicing English writing.

In order to prepare for the CET, I spend more time $\begin{array}{lllll}7.3 & 51.3 & 33.3 & 8\end{array}$ reading English newspapers.

Taking or preparing for the CET makes me pay more $\quad \begin{array}{llll}13.3 & 39.3 & 36.7 & 10.7\end{array}$ attention to English use in real life.

\begin{tabular}{llllll}
\hline The CET makes me feel that the English language is a & 11.3 & 41.3 & 36 & 11.3
\end{tabular} very useful tool.

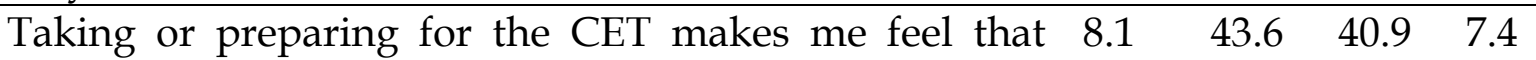
learning English is more important.

In order to prepare for the CET, I spend more time $\begin{array}{lllll}3.3 & 24 & 52.7 & 20\end{array}$ learning English and American literature.

Note: $\mathrm{SA}=$ Strongly Agree, $\mathrm{A}=$ Agree, $\mathrm{D}=$ Disagree, $\mathrm{SD}=$ Strongly Disagree. All the numbers in the cells are percentages.

However, the extra time students stated they would spend on specific language skills varied. For example, as many as $72 \%$ of students agreed or strongly agreed that they would spend more time memorizing English words, which provides evidence that rote memorization is deeply rooted in Chinese students' English-learning practices (Li, 2005). In addition, approximately $70 \%$ of the students agreed or strongly agreed that they would spend more time watching English movies and listening to English broadcasts. This agrees with Hua's (2006) observation that students spent more time on listening and speaking than on other skills, possibly as a result of the greater focus the new version of the CET on communicative skills. Less than $60 \%$ of the students agreed or strongly agreed that they would spend more time reading English newspapers. It seems that students learned English not only from books but also from other channels; however, newspapers were not as popular as movies or broadcasts for college students' English learning. Those who agreed or strongly agreed that they would spend more time practicing English-Chinese translation totaled $66.4 \%$, whereas $64.7 \%$ agreed or strongly agreed that they would spend more time practicing English writing. Translation and writing are assessed in the CET but each has a relatively low weight, with the former accounting for $5 \%$ and the latter accounting for $15 \%$ of the total score. About $52.6 \%$ of the students agreed or strongly agreed that they would pay more attention to English use in real life. This relatively low percentage might be explained by the fact that it is difficult for standardized language tests to directly assess authentic language use in real life, especially when most of the questions are framed in a multiple-choice format. Finally, only $27.3 \%$ of the students agreed or strongly agreed that they would spend more time learning English and American literature. One potential reason for this low percentage could be that English literature is not directly tested in the CET.

\section{Self-Efficacy and Anxiety}

Self-efficacy is defined as how people feel about their ability to produce designated levels of performance that exercise influence over events that affect their lives (Bandura,1994). As shown in Table 5, about half the students agreed or strongly 
agreed that they felt more confident about their English reading and listening ability as a result of taking or preparing for the CET, whereas less than $40 \%$ felt the same way about their speaking and writing ability. Reading has always been a focus of the CET, whereas the weight given to listening was raised from $20 \%$ to $35 \%$ in 2006 . It is plausible to expect, therefore, that students may have put more effort into reading and listening and consequently felt more confident about their reading and listening ability. In contrast, speaking is optional in the CET, and writing only accounts for $15 \%$ of the CET total score. It is reasonable to surmise, therefore, that this partially explains the relatively less increase of self-efficacy in terms of speaking and writing. Furthermore, around $47 \%$ of students felt more confident about their overall English proficiency, and about $42 \%$ felt more capable of using English in real situations as a result of taking or preparing for the CET.

Table 5

Self-Efficacy

\begin{tabular}{|c|c|c|c|c|}
\hline Items & SA & $\mathrm{A}$ & $\mathrm{D}$ & SD \\
\hline $\begin{array}{l}\text { I feel more confident about my English-reading ability } \\
\text { as a result of taking or preparing for the CET. }\end{array}$ & 3.3 & 50 & 40 & 6.7 \\
\hline $\begin{array}{l}\text { I feel more confident about my English-listening ability } \\
\text { as a result of taking or preparing for the CET. }\end{array}$ & 7.3 & 42.7 & 42 & 8 \\
\hline $\begin{array}{l}\text { I feel more confident about my overall English } \\
\text { proficiency as a result of taking or preparing for the } \\
\text { CET. }\end{array}$ & 4.7 & 42.7 & 46 & 6.7 \\
\hline $\begin{array}{l}\text { I feel more able to use English in real situations as a } \\
\text { result of taking or preparing for the CET. }\end{array}$ & 4 & 38 & 48 & 10 \\
\hline $\begin{array}{l}\text { I feel more confident about my English-speaking } \\
\text { ability as a result of preparing for the CET. }\end{array}$ & 4.7 & 32.7 & 48 & 14.7 \\
\hline $\begin{array}{l}\text { I feel more confident about my English-writing ability } \\
\text { as a result of taking or preparing for the CET. }\end{array}$ & 2 & 34 & 54 & 9.5 \\
\hline
\end{tabular}

Note: $\mathrm{SA}=$ Strongly Agree, $\mathrm{A}=$ Agree, $\mathrm{D}=$ Disagree, $\mathrm{SD}=$ Strongly Disagree. All the numbers in the cells are percentages.

Anxiety, defined as the "subjective feeling of tension, apprehension, nervousness, and worry associated with an arousal of the automatic nervous system" (Spielberger, 1983, p. 1), is also an important aspect of the test's impact. As shown in Table 6 , over $80 \%$ of the students agreed or strongly agreed that they were under greater pressure because of taking or preparing for the CET, and almost 70\% agreed or strongly agreed that they were experiencing more anxiety in terms of learning English. A certain level of anxiety may promote learning, though too much may function as an obstacle in this regard (Kirkland, 1971). Thirty-eight percent of the students agreed or strongly agreed that taking or preparing for the CET made them feel that they had failed in their efforts to learn English. Around one third of the students agreed or strongly agreed that they felt more frustrated with learning English and had become more afraid of learning English. This is somewhat in contrast with the increasing self-efficacy they reported in terms of their English 
ability, as illustrated in Table 5. This contrast may represent the actual situation regarding students' perceptions of the impact of the CET. On the one hand, students felt more confident about their English ability as a result of putting more effort into preparing for the CET. On the other hand, the test preparation put them under great pressure, such that they became more anxious about and frustrated with learning English.

Table 6

Anxiety

\begin{tabular}{|c|c|c|c|c|}
\hline Items & SA & $\mathrm{A}$ & $\mathrm{D}$ & SD \\
\hline $\begin{array}{l}\text { I am under greater pressure to learn English because of } \\
\text { taking or preparing for the CET. }\end{array}$ & 18.4 & 65.3 & 14 & 2 \\
\hline $\begin{array}{l}\text { Taking or preparing for the CET makes me feel more } \\
\text { anxious about learning English. }\end{array}$ & 10.7 & 58 & 28 & 3.3 \\
\hline $\begin{array}{l}\text { Taking or preparing for the CET makes me feel that I } \\
\text { have failed in my efforts to learn English. }\end{array}$ & 6.7 & 31.3 & 53 & 9.3 \\
\hline $\begin{array}{l}\text { Taking or preparing for the CET makes me more } \\
\text { frustrated with learning English. }\end{array}$ & 6 & 27.3 & 53 & 13.3 \\
\hline $\begin{array}{l}\text { I am more afraid of learning English because of taking } \\
\text { or preparing for the CET. }\end{array}$ & 6.1 & 25 & 56 & 12.8 \\
\hline
\end{tabular}

Note: $\mathrm{SA}=$ Strongly Agree, $\mathrm{A}=$ Agree, $\mathrm{D}=$ Disagree, $\mathrm{SD}=$ Strongly Disagree. All the numbers in the cells are percentages.

\section{Conclusion}

Based on evidence from the questionnaire survey, the CET seems to have had a pervasive impact on the participating students in this study. First, the CET has a greater impact on learning content than on learning methods. The CET seems to be effective in directing students' attention to what they need to learn in order to pass it. This finding is consistent with previous literature showing that tests have a greater impact on the content taught than on the methods used to teach it. Second, over half of the students felt that the CET had caused them to clarify their Englishlearning goals, and over $80 \%$ of the students were more motivated to make a greater effort to learn English. A pattern seemed to emerge whereby the students usually expressed their willingness to match their effort to learn respective language skills in accordance with their weight in the CET. Therefore, many students were willing to put more effort into listening and reading and less effort into writing and speaking. Third, about half the students reported a higher level of self-efficacy in regard to their overall English ability and to different English skills as a result of preparing for or taking the CET. Despite the increasing self-efficacy, however, almost $70 \%$ of the students reported that they felt more pressure and anxiety as a result of preparing for or taking the CET, and around one third of the students felt more frustrated with learning English and became more afraid of learning English. Overall, the findings of this study provide some evidence for the intensity and range of the impact of the CET on students' English learning, both in terms of their English-learning practices and affective conditions. 
The English education in China has been characterized by "concentration on intensive learning, preoccupation with examinations of grammatical structures, memorization and rote learning of vocabulary, and lack of attention to more communicative skills" (Harvey, 1990, cited in Qi, 2005, p. 145). And, in fact, a frequent criticism of the CET is that it promotes such practices as rote memorization. As with many other large-scale standardized tests, for the purpose of efficiency, the CET relies heavily on multiple-choice items. As a result, some lower-level language skills such as vocabulary and grammar are emphasized, whereas higher-level communicative skills may not receive adequate attention. Given the importance of the CET in college English education, it is not surprising to find that many undergraduate students focus on reciting English words and practicing English grammar exercises (Wang, 2010). Fortunately, the CET committee has taken some steps to address this issue (Zheng \& Cheng, 2008). For instance, since 2006, the test has given more weight to communicative skills and removed the direct assessment of vocabulary and sentence structure from the multiple-choice items. The current study has found that students seem to be sensitive to what is assessed in the CET and the weight it gives to different language skills. Given the CET's powerful impact on college English education, it is important that the CET committee keep reforming the test and adopt more authentic measures of English-language ability in order to encourage students to take more interest in English-language use in real-world contexts.

As described by Shohamy (2001, p. 113), high-stakes tests can have detrimental effects on individuals "as they can create winners and losers, successes and failures, rejections and acceptances." In the present study, most of the students were motivated to learn English as a result of preparing for or taking the CET, yet the CET also made many of them feel more anxious about and frustrated with their efforts to learn English. These negative emotional effects are likely to be related to the high stakes inhering in success or failure on the CET. Although this was not intended by the CET committee, some Chinese universities use the CET results as a basis for awarding a bachelor's degree and some employers also require the CET score reports. The debate over whether test developers are responsible for how tests are used has long been in progress, and Jin $(2008$, p.1) used the phrase "powerful tests, powerless test designers" to describe this difficult situation. As recommended by the Code of Ethics for the International Language Testing Association (2000), "language testers shall regularly consider the potential effects, both short and long term on all stakeholders of their projects, reserving the right to withhold their professional services on the grounds of conscience." Although the CET committee cannot control how the test results are used by universities or employers, more empirical studies should be conducted to validate or invalidate certain ways of using the CET test results, and the CET committee would be the best agent to coordinate or promote such efforts.

\section{Limitations and Future Studies}

The university where the current study took place had a relatively relaxed policy in regard to the CET. For example, if undergraduates are not able to achieve a certain score on the CET-4 before graduation, they can still earn their bachelor's degrees, as 
long as they pass a school-based English proficiency test that is less challenging than the CET-4.However, for the universities that use earning a certain score on the CET as a degree requirement, the CET is likely to have higher stakes for their students and thus may bring stronger effects. The stakes of the CET are thus context-based. In addition to the premise that the perceptions of the CET could be different at different universities, the impact of the CET on students may also interact with students' individual characteristics, such as their English proficiency, gender, social economic status (SES), and affective conditions. It is expected that students with lower English proficiency may experience a correspondingly greater negative impact from the CET (Green, 2006). However, given that some of the participating students had not yet taken the CET-4, there is a lack of a common measure of students' English proficiency in the present study. Also, as the present study collected data from only one university with students having similar college entrance examination scores, there is little variation in students' English proficiency. Therefore, it is necessary to expand this research to involve students from different universities with heterogeneous English-proficiency levels and family backgrounds in order to explore individual differences related to their perceptions.

To understand the general perceptions of the impact of the CET, we recruited participants from different grade levels at college. The third-year and fourth-year students had taken the CET, whereas the first-year and the second-year students were preparing to take the CET when they responded to the survey. Many of the survey items were thus designed to cater to the wide range of participants' experience with the CET, such as "I have taken or will take the CET coaching classes." If a study goal is to compare the "veteran" CET-takers' versus "future" CET-takers' perceptions, it would be wise to build different versions of items for these two groups of participants. For example, the item could be written as "I have taken the CET coaching classes" for "veteran" CET-takers and "I will take the CET coaching classes" for "future" CET-takers. Another limitation is that unequal sample sizes by gender and school year were used in this study. More male students and more fourth-year students should be included in further studies in order to gain a more balanced perspective on the CET.

Finally, students' self-reported responses to the survey are the only evidence used in this study. It would be helpful to collect other types of evidence, such as observations and interviews, to gain a more in-depth understanding of how and why students had particular perceptions of the impact of the CET. Nevertheless, the current study constitutes only a first step in investigating the impact of the CET on students at one university. Additional long-term and follow-up studies at different types of universities are needed in order to learn about the nature of the CET's impact in a variety of settings. 


\section{References}

Alderson, J. C., \&Hamp-Lyons, L. (1996). TOEFL preparation courses: A study of washback. Language Testing, 13(3), 280-297.

Alderson, J. C., \& Wall, D. (1993). Does washback exist? Applied Linguistics, 14(2), 115-129.

Anderman, E. M., Austin, C. C., \& Johnson, D. M. (2002). The development of goal orientation. In A. Wigfield, \& J. S. Eccles (Eds.), Development of achievement motivation (pp. 197-220). San Diego, CA: Academic Press.

Andrews, S., Fullilove, J., \& Wong, Y. (2002). Targeting washback: A case study. System, 30(2), 207-223.

Bandura, A. (1994). Self-efficacy. In V. S. Ramachaudran (Ed.), Encyclopedia of human behavior (Vol. 4, pp. 71-81). New York:, NY Academic Press.

Burrows, C. (2004). Washback in classroom-based assessment: A study of the washback effect in the Australian Adult Migration Program. In L. Cheng, Y. Watanabe, \& A. Curtis (Eds.), Washback in language testing - Research contexts and methods (pp. 113-128). Mahwah, NJ: Lawrence Erlbaum.

Cai, J. (2005). ELT at the tertiary level in China: Review, reflection and research. Shanghai, China: Fudan University Press.

Chen, F. (2007). The washback effect of College English Test Band 4 on curricular planning and instruction. CELEA Journal, 30(1), 19-29.

Chen, H. (2008). The influence of the College English Test Band 4 and Band 6 on College English teaching. Chinese and Foreign Education Research, 10, 35-37.

Cheng, L. (1997). Does washback influence teaching? Implications for Hong Kong. Language and Education, 11(1), 38-54.

Green, A. (2006). Watching for washback: Observing the influence of the International English Language Testing System academic writing test in the classroom. Language Assessment Quarterly, 3(4), 333-368.

Gu, X. (2005). Positive or negative? An empirical study of CET washback on college English teaching and learning in China (Unpublished doctoral dissertation). Shanghai Jiaotong University, Shanghai, China.

Gu, X., Yang, Z., Liu, X. (2011). A longitudinal case study of CET washback on college English classroom teaching in China. Paper presented at the $33^{\text {rd }}$ Language Testing Research Colloquium, Ann Arbor, MI.

Hamp-Lyons, L., \& Brown, A. (2005). TOEFL impact study report (Unpublished report). University of Melbourne, Victoria, Australia.

Han, B., Dai, M., \& Yang L. (2004). Analyzing the problems of the College English Test based on a survey. Foreign Languages and Their Teaching, 179(2), 17-23.

Harlen, W., \& Deakin-Crick, R. (2003).Testing and motivation for learning. Assessment in Education, 10(2), 169-208.

Harvey, P. (1990). A lesson to be learned: Chinese approach to language learning. In Dzau, Y. F. (Ed.), English in China (pp.168-174). Hong Kong: API Press.

Hawkey, R. (2006). Impact theory and practice: Studies of the IELTS test and Progettolingue 2000. Cambridge: Cambridge University Press.

Hayes, B., \& Read, J. (2004). IELTS test preparation in New Zealand: Preparing students for the IELTS academic module. In L. Cheng, Y. Watanabe, \& A. 
Curtis (Eds.), Washback in language testing - Research contexts and methods (pp. 97-111). Mahwah, NJ: Lawrence Erlbaum.

Hua, S. (2006). An empirical study of washback from CET-4 on college English teaching and learning. CELEA Journal, 29(1), 54-59.

Huang, D., \& Yang, L. (2002). Analyzing the problems of the College English Test based on a survey. Foreign Language Testing and Research, 4, 288-293.

Hughes, A. (1989). Testing for language teachers. Cambridge, UK: Cambridge University Press.

Hughes, A. (1993). Backwash and TOEFL (Unpublished manuscript). University of Reading, England.

International Language Testing Association. (2000). Code of ethics. Retrieved June 1, 2011 from http:/ / www.iltaonline.com/images/pdfs/ILTA_Code.pdf

Jin, Y. (2008). Powerful tests, powerless test designers? Challenges facing the college English test. CELEA Journal, 31(5), 1-11.

Jin, Y., \& Yang, H. (2006). The English proficiency of college and university students in China: As reflected in the CET. Language Culture and Curriculum, 19(1), 2136.

Kirkland, M. C. (1971). The effect of tests on students and schools. Review of Educational Research, 41(4), 303-350.

Li, H. (2009). Are teachers teaching to the test? A case study of the College English Test (CET) in China. International Journal of Pedagogies and Learning, 5(1), 25-36.

Li, X. (2005). An analysis of Chinese EFL learners' beliefs about the role of rote learning in vocabulary learning strategies. Asian EFL Journal, 7(4). Retrieved from http:/ / www.asian-efl-journal.com/xiuping_11-05_thesis.pdf

Li, Z., \& Su, W. (2006). Socio-cultural background and Chinese English majors learning styles. CELEA Journal, 29(3), 72-81.

Ministry of Education, P. R. China. (2004). National college English curriculum requirements.

Pintrich, P., \& Schunk, D. (1996). Motivation in education: Theory, research $\mathcal{E}$ applications. Englewood Cliffs, NJ: Prentice-Hall.

Qi, L. (2005). Stakeholders' conflicting aims undermine the washback functions of a high-stakes test. Language Testing, 22(2), 142-173.

Qi, L. (2007). Is testing an efficient agent for pedagogical change? Examining the intended washback of the writing task in a high-stakes English test in China. Assessment in Education, 14(1), 51-74.

Rao, Z. (2001). Matching teaching styles with learning styles in East Asian contexts. The Internet TESL Journal, 7(7). Retrieved from http:/ /iteslj.org/Techniques/Zhenhui-TeachingStyles.html

Rea-Dickins, P. (1997). So, why do we need relationships with stakeholders in language testing? A view from the UK. Language Testing, 14(3), 304-314.

Ross, S. J. (2008). Language testing in Asia: Evolution, innovation, and policy challenges. Language Testing, 25(1), 5-13.

Shohamy, E. (2001). The social responsibility of the language testers. In R. L. Cooper, E. Shohamy, \& J. Walter (Eds.), New perspectives and issues in educational language policy: A festschrift for Bernard DovSpolsky, (Vol. in honor of Bernard Spolsky, pp. 113-130). Philadelphia, PA: John Benjamins North America. 
Spielberger, C. D. (1983). Manual for the state-trait anxiety inventory (STAI). Palo Alto, CA: Consulting Psychologists Press.

Suen, H. K., \& Yu, L. (2006). Chronic consequences of high-stakes testing? Lessons from the Chinese civil service exam. Comparative Education Review, 58(1), 4665.

Taylor, L. (2005). Key concepts in ELT: Washback and impact. ELT Journal, 59(2), 154-155.

Tsagari, C. (2006). Investigating the washback effect of the first certificate in English examination in Greek private language schools (Unpublished doctoral dissertation). Lancaster University, Lancaster, UK.

Wall, D. (1997). Impact and washback in language testing. In C. Clapham, \& D. Corson (Eds.), Encyclopedia of language and education. Volume 7: Language Testing and Assessment, (pp. 291-302). Dordrecht, The Netherlands: Kluwer Academic Publishers.

Wall, D. (2000). The impact of high stakes testing on teaching and learning: Can this be predicted or controlled? System, 28(4), 499-509.

Wall, D., \& Horak, T. (2007). Using baseline studies in the investigation of test impact. Assessment in Education, 14(1), 99-116.

Wang, W. (2010). Evaluation on washback effects of College English Test Band 4. Sino-US English Teaching, 7(2), 35-40.

Wang, X., Wang, J., \& Liu, F. (2005). CET validity: An analytical study based on the feedback from the questionnaires. Journal of Heibei Institute of Architectural Science and Technology (Social Science Edition), 22(1), 109-110.

Watanabe, Y. (1996). Does grammar translation come from the entrance examination? Preliminary findings from classroom-based research. Language Testing, 13(3), 318-333.

Yang, H. (2003). The 15 years of the CET and its impact on teaching. Journal of Foreign Languages, 145(3), 21-29.

$\mathrm{Yu}, \mathrm{W}$. (2005). The student survey and analysis on the reform of College English Test Band 4 and Band 6. China College Teaching, 7, 43-47.

Zhang, Y., \& Elder, C. (2009). Measuring the speaking proficiency of advanced EFL learners in China: The CET-SET solution. Language Assessment Quarterly, 6(4),298-314.

Zheng, Y., \& Cheng, L. (2008). Test review: College English Test (CET) in China. Language Testing, 25(3), 408-417. 